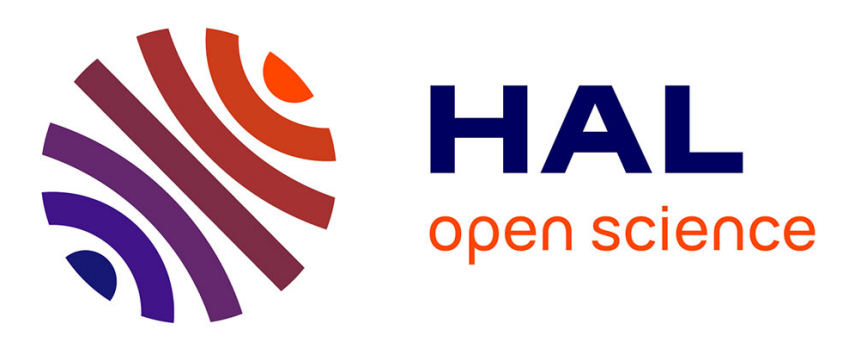

\title{
Homologous Recombination is Involved in the Repair Response of Mammalian Cells to Low Doses of Tritium
}

\author{
Yannick Saintigny, Stéphane Roche, Delphine Meynard, Bernard S Lopez
}

\section{To cite this version:}

Yannick Saintigny, Stéphane Roche, Delphine Meynard, Bernard S Lopez. Homologous Recombination is Involved in the Repair Response of Mammalian Cells to Low Doses of Tritium. Radiation Research, 2008, 170 (2), pp.172-183. 10.1667/RR1089.1 . hal-01621200

\section{HAL Id: hal-01621200 \\ https://hal.science/hal-01621200}

Submitted on 13 Dec 2017

HAL is a multi-disciplinary open access archive for the deposit and dissemination of scientific research documents, whether they are published or not. The documents may come from teaching and research institutions in France or abroad, or from public or private research centers.
L'archive ouverte pluridisciplinaire $\mathbf{H A L}$, est destinée au dépôt et à la diffusion de documents scientifiques de niveau recherche, publiés ou non, émanant des établissements d'enseignement et de recherche français ou étrangers, des laboratoires publics ou privés. 


\title{
Homologous Recombination is Involved in the Repair Response of Mammalian Cells to Low Doses of Tritium
}

\author{
Yannick Saintigny, ${ }^{1}$ Stéphane Roche, ${ }^{1,2}$ Delphine Meynard and Bernard S. Lopez ${ }^{3}$ \\ Institut de Radiobiologie Cellulaire et Moléculaire, CEA-CNRS UMR217, 92265 Fontenay aux Roses, Cédex, France
}

\begin{abstract}
Saintigny, Y., Roche, S., Meynard, D. and Lopez, B. S. Homologous Recombination is Involved in the Repair Response of Mammalian Cells to Low Doses of Tritium. Radiat. Res. 170, 172-183 (2008).
\end{abstract}

Radioactive compounds incorporated in tissues can have biological effects resulting from energy deposition in subcellular compartments. We addressed the genetic consequences of $\left[{ }^{3} \mathbf{H}\right]$ or $\left[{ }^{14} \mathrm{C}\right]$ thymidine incorporation into mammalian DNA. Low doses of $\left[{ }^{3} \mathrm{H}\right]$ thymidine in $\mathrm{CHO}$ cells led to enhanced sensitivity compared with $\left[{ }^{14} \mathrm{C}\right]$ thymidine. Compared with wild-type cells, homologous recombination (HR)-deficient cells were more sensitive to lower doses of $\left[{ }^{3} \mathrm{H}\right]$ thymidine but not to any dose of $\left[{ }^{14} \mathrm{C}\right]$ thymidine. $\mathrm{XRCC4}$-defective cells, however, were sensitive to both low and high doses of $\left[{ }^{3} \mathrm{H}\right]$ and $\left[{ }^{14} \mathrm{C}\right]$ thymidine, suggesting introduction of DNA double-strand breaks, which were confirmed by $\gamma-\mathrm{H} 2 \mathrm{AX}$ focus formation. While $\gamma$ rays induced measurable HR only at toxic doses, sublethal levels of $\left[{ }^{3} \mathrm{H}\right]$ or $\left[{ }^{14} \mathrm{C}\right]$ thymidine strongly induced $\mathrm{HR}$. The level of stimulation was in an inverse relationship to the emitted energies. The $R A D 51$ gene conversion pathway was involved, because $\left[{ }^{3} \mathrm{H}\right]$ thymidine induced RAD51 foci, and $\left[{ }^{3} \mathrm{H}\right]$ thymidine-induced HR was abrogated by expression of dominant negative RAD51. In conclusion, both HR and nonhomologous end-joining pathways were involved after labeled nucleotide incorporation (low doses); genetic effects were negatively correlated with the energy emitted but were positively correlated with the energy deposited in the nucleus, suggesting that low-energy $\beta$-particle emitters, at non-toxic doses, may induce genomic instability. $\odot 2008$ by Radiation Research Society

\section{INTRODUCTION}

Environmental concerns have been raised by the use of both naturally occurring and synthetic radioactive compounds, which can cause external or internal exposure to ionizing radiation. In the case of external exposure, only radioactive sources emitting sufficiently penetrating radia-

\footnotetext{
${ }^{1}$ The authors made equal contributions.

${ }^{2}$ Present address: Hôpital Saint Eloi, Laboratoire de Biochimie, 80 Avenue A. Fliche, 34295 Montpellier Cedex 5, France.

${ }^{3}$ Address for correspondence: Institut de Radiobiologie Cellulaire et Moléculaire, CEA-CNRS UMR217, 18 route du Panorama, 92265 Fontenay aux Roses, Cédex, France; e-mail: bernard.lopez@cea.fr.
}

tion reach cellular targets and cause biological effects. However, radioactive compounds emitting rays with low penetrating energy can also have a biological impact if they are incorporated into cells and tissues, causing in situ selfirradiation. Moreover, the low penetration becomes an amplifying factor because energy is focused in the vicinity of the incorporated isotope.

In the present work, we address the genetic consequences of incorporation of non-lethal amounts of labeled thymidine into mammalian cell DNA. Because of the low energy deposition and low penetration depth, ${ }^{3} \mathrm{H}$-labeled nucleotides release their energy to any structures in proximity (e.g. DNA). We compared the effects of $\left[{ }^{3} \mathrm{H}\right]$ thymidine on cell viability, DNA double-strand break (DSB) formation, and homologous recombination (HR) with those of thymidine labeled with ${ }^{14} \mathrm{C}$. Since the ${ }^{3} \mathrm{H}$ and ${ }^{14} \mathrm{C}$ isotopes emit different energies- $0.019 \mathrm{MeV}$ and $0.157 \mathrm{MeV}$, respectively-their actual energy depositions in the cell nucleus are different, corresponding to $68 \%$ and $19 \%$, respectively (1). This provides a model to evaluate biological effects as a function of the energy actually deposited in the nucleus.

Lethal and genetic effects induced by ${ }^{3} \mathrm{H}$ have been described for mammalian cells (2-9). HR induced by $\left[{ }^{3} \mathrm{H}\right]$ uracil or tritiated water have been described in yeast $(10,11)$. Using updated methods, cellular responses to labeled thymidine can now be addressed at the molecular level, and the pathways involved can be characterized in mammalian cells.

We report here the induction of DSBs by sublethal doses of incorporated labeled thymidine, as revealed by $\gamma$-H2AX focus formation. Since DSBs can be repaired by non-homologous end joining (NHEJ) or HR in mammalian cells, we first studied the consequences of a defect either in HR or in XRCC4, a component of the primary NHEJ repair pathway, on cell survival after labeled thymidine incorporation. We then analyzed the molecular and genetic effects of labeled thymidine incorporation on HR.

To analyze HR at the molecular level, we used a wellcharacterized intrachromosomal substrate. Strategies employing such substrates have been widely used in different cell lines, in different genetic backgrounds, and at different loci. Thus, although there might be hot and cold regions for HR, and that generalization to the genome is by extrap- 
olation, this strategy is the most precise to monitor HR at defined, and controlled, molecular levels. The influence of the HR protein RAD51 was analyzed using a dominant negative form of RAD51 and measuring the induction of RAD51 foci. We also compared the lethal effects and HR induced by $\left[{ }^{3} \mathrm{H}\right]$ thymidine incorporation, $\left[{ }^{14} \mathrm{C}\right]$ thymidine incorporation, and external exposure to ${ }^{137} \mathrm{Cs} \gamma$ radiation, which emits high-energy $(0.662 \mathrm{MeV})$ and highly penetrating $\gamma$ rays.

\section{MATERIALS AND METHODS}

\section{Cell Lines}

We used a collection of Chinese hamster cell lines containing an intrachromosomal recombination substrate as depicted in Fig. 1A (12). This substrate contains a direct repeat of two inactive neomycin-resistant (NEO) genes, which can be restored to a functional NEO gene through recombination. The parental cells are sensitive to G418, but the recombinants are G418-resistant (12). Cells were maintained at $37^{\circ} \mathrm{C}$ with $95 \%$ air $/ 5 \% \mathrm{CO}_{2}$ in Dulbecco's modified Eagle's medium (DMEM) supplemented with $10 \%$ fetal bovine serum.

The CHO-DRA10 cell line is derived from the CHO-K1 hamster line and harbors an intrachromosomal substrate that monitors HR (12). SM-RAD514 is a CHO-DRA10 cell line that expresses the dominant negative SMRAD51 gene (Fig. 1B), which inhibits spontaneous as well as induced HR (13). Thus both CHO-DRA10 and SMRAD51-4 cells bear the same recombination substrate at the same locus (Fig. 1B). The XR-1 hamster cell line is defective for the XRCC4 gene, a co-factor of DNA ligase IV that is involved in the late steps of NHEJ, and is highly sensitive to ionizing radiation (14). X4V is an XR-1 line complemented with human XRCC4 cDNA (15). Information on all the cell lines is summarized in Fig. 1C.

\section{Radioactive Labeling of Cells}

[Methyl- ${ }^{3} \mathrm{H}$ ]dThd $(45 \mathrm{Ci} / \mathrm{mmol}, 1.67 \mathrm{TBq} / \mathrm{mmol})$ or $\left[\right.$ methyl- ${ }^{14} \mathrm{C}$ ]dThd $(58 \mathrm{mCi} / \mathrm{mmol}, 2.15 \mathrm{TBq} / \mathrm{mmol})$, purchased from Amersham (GE Healthcare Europe, Orsay, France), was diluted in regular medium. Cells were contaminated during asynchronous exponential growth at the same stoichiometric concentration $(0.1 \mathrm{mM})$ but at various specific activities $(0.05-$ $5 \mu \mathrm{Ci} / \mathrm{ml}, 1.85-185 \mathrm{kBq} / \mathrm{ml})$. Cells were incubated for $20 \mathrm{~h}$ at $37^{\circ} \mathrm{C}$ with $95 \%$ air $/ 5 \% \mathrm{CO}_{2}$, at which time incorporation reached a plateau; over $95 \%$ of cells contained labeled nucleotides. Radioactive medium was then discarded, and cells were washed twice in phosphate-buffered saline before processing (Fig. 1D). Experiments were repeated at least three times.

\section{Gamma Irradiation}

Cells in PBS were irradiated during exponential, asynchronous growth using a ${ }^{137} \mathrm{Cs}$ irradiator $(2 \mathrm{~Gy} / \mathrm{min})$ at the indicated doses and then were incubated in DMEM at $37^{\circ} \mathrm{C}$ for $20 \mathrm{~h}$ before processing. Experiments were repeated three times.

\section{Measurement of Homologous Recombination}

Cells were trypsinized, counted and divided into three fractions. The first fraction was used to measure the incorporation of labeled nucleotides, the second was used to measure the colony-forming efficiency, and the third was plated with $1 \mathrm{mg} / \mathrm{ml} \mathrm{G} 418$ to measure the recombination frequency. Experiments were repeated more than three times.

\section{Measurement of Labeled Nucleotides Incorporated into DNA}

Cells were suspended, and DNA was precipitated in ice-cold 10\% trichloroacetic acid (TCA). Precipitated DNA was recovered on GF/C filters (Whatman) that were then washed with $10 \%$ and 5\% TCA. Incorporation of $\left[{ }^{3} \mathrm{H}\right]$ or $\left[{ }^{14} \mathrm{C}\right]$ thymidine into DNA was determined by liquid scintillation counting of the filters. The incorporation rate was expressed as disintegrations per minute (dpm) per $10^{6}$ cells. We estimated the dose delivered into each nucleus using conversion factors described elsewhere (1). For ${ }^{3} \mathrm{H}$ incorporated into the nucleus, the conversion factor is 1 disintegration $=2.7 \times 10^{-3} \mathrm{~Gy}$; for ${ }^{14} \mathrm{C}, 1$ disintegration $=1.9 \times 10^{-3} \mathrm{~Gy}$. The doses were calculated for a 20 -h incorporation.

\section{Western Blotting and Immunofluorescence}

All cell extraction steps were performed at $4^{\circ} \mathrm{C}$. After cells were washed with PBS, they were suspended in lysis buffer $(25 \mathrm{~m} M$ Tris, $\mathrm{pH}$ 7.5, $5 \mathrm{~m} M$ EDTA, $600 \mathrm{~m} M \mathrm{NaCl}, 1 \mathrm{~m} M$ DTT, 0.1\% NP40, $5 \mu \mathrm{g} / \mathrm{ml}$ leupeptin, $2 \mu M$ pepstatin, $1 \mathrm{mM}$ PMSF) and were incubated for $30 \mathrm{~min}$ on ice. Extracts were centrifuged for $30 \mathrm{~min}$ at $15,000 \mathrm{~g}$, the supernatant was recovered and protein concentration was determined using the BioRad protein assay. Boiled samples $(50 \mu \mathrm{g} / \mathrm{well})$ were loaded on a $10 \%$ polyacrylamide gel for electrophoresis in the presence of SDS. After migration, the proteins were electrotransferred to a nitrocellulose membrane and probed with specific anti-human RAD51 antibodies (Oncogene Research). Standard procedures were used for electrophoresis, transfer and Western blotting. Visualization was done with an ECL detection kit (Amersham).

The RAD51 foci were analyzed as described previously (16) using anti-RAD51 antibody (Pharmingen, VWR, France). The $\gamma$-H2AX foci were analyzed as described previously (17) using anti-phospho-H2AX antibody (Upstate, Lake Placid, NY). Cells were incubated for $20 \mathrm{~h}$ with [methyl- ${ }^{3} \mathrm{H}$ ]dThd or $\left[\right.$ methyl $-{ }^{14} \mathrm{C}$ ]dThd and were then fixed (methanol/ acetone) and stained. Experiments were repeated three times with a minimum of 100 nuclei per incorporated dose scored in each experiment.

\section{Cell Cycle Analysis}

Trypsinized cells were collected by centrifugation ( $5 \mathrm{~min}$ at $2000 \mathrm{~g}$ ), resuspended in $500 \mu \mathrm{l}$ PBS, and fixed by adding $1.5 \mathrm{ml}$ cold ethanol. Cells were then treated with propidium iodide $(50 \mu \mathrm{g} / \mathrm{ml})$ and RNase $(25$ $\mu \mathrm{g} / \mathrm{ml}$ ). DNA content was measured by flow cytometry (FACSCalibur, Becton Dickinson France SAS, Le Pont-De-Claix, France). For each aquisition, 10,000 and 20,000 cells were scored for ${ }^{137} \mathrm{Cs}$ external $\gamma$ radiation and labeled nucleotide incorporation, respectively. Cell cycle distributions were analyzed using the Dean-Jett-Fox model on FlowJo software (TreeStar, Inc. Ashland, OR). Dead cells, debris and doublets were excluded from the data analysis.

\section{Data Plotting and Statistical Analysis}

In contrast to $\gamma$ radiation, nucleotide incorporation varies among repeated experiments. As a consequence, averages and standard deviations cannot be calculated and plotted; all data were graphed as scatter plots. Then we calculated the Spearman's Rho rank correlation coefficient $\left(r_{s}\right)$ for the relationship between two non-normally distributed variables. This provided for analysis of the nonlinear relationship between radioisotope cellular contamination and the biological end points (colony-forming efficiency, HR, foci). All results showed a significant Spearman's Rho rank correlation coefficient. Regression curves were calculated using a Gaussian convolution data transformation of the non-linear distributions. Comparisons between regression curves used the Wilcoxon matched pairs test. All analyses were done using Prism (GraphPad Software, Inc. San Diego, CA).

\section{RESULTS}

\section{Cell Cycle Distributions after $\left[{ }^{14} \mathrm{C}\right]$ or $\left[{ }^{3} \mathrm{H}\right]$ Thymidine Incorporation}

Cells were treated with $\left[{ }^{3} \mathrm{H}\right]$ thymidine or $\left[{ }^{14} \mathrm{C}\right]$ thymidine (Fig. 1) and analyzed using a fluorescence-activated cell 

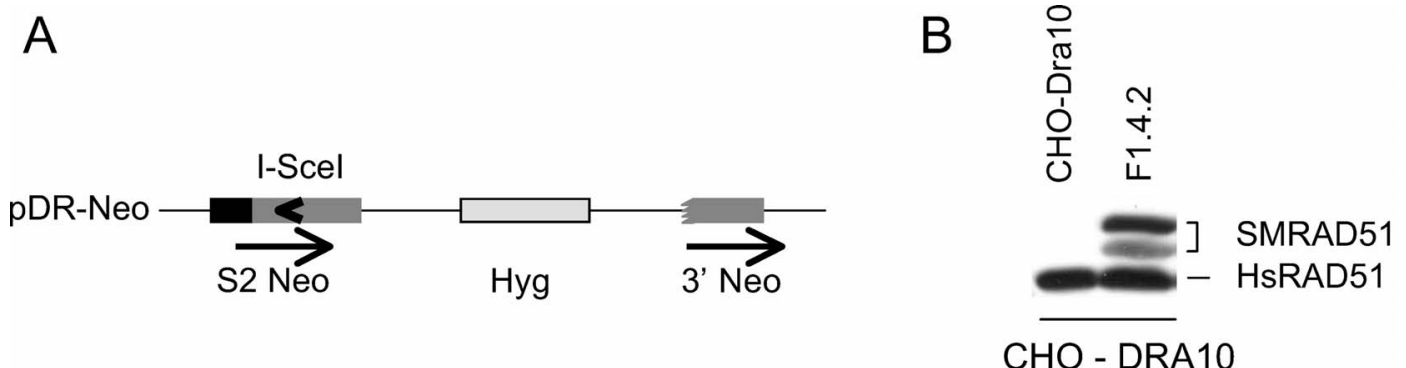

CHO - DRA10

C

\begin{tabular}{lcccc}
\hline Name & Cell line & Species & HR subtrate & Genotype \\
\hline XR-1 & XR-1 & Hamster & & $\begin{array}{c}\text { Xrcc4-/- } \\
\text { X4V }\end{array}$ \\
XR-1 & Hamster & & $\begin{array}{c}\text { XR-1 complemented by V5- } \\
\text { tagged HsXRCC4 }\end{array}$ \\
CHO-DRA10 & CHO & Hamster & pDR-Neo & \\
F1.4.2 & CHO & Hamster & pDR-Neo & $\begin{array}{c}\text { DRA10 expressing dominant } \\
\text { negative SMRad51 }\end{array}$ \\
\hline
\end{tabular}

$\mathrm{D}$

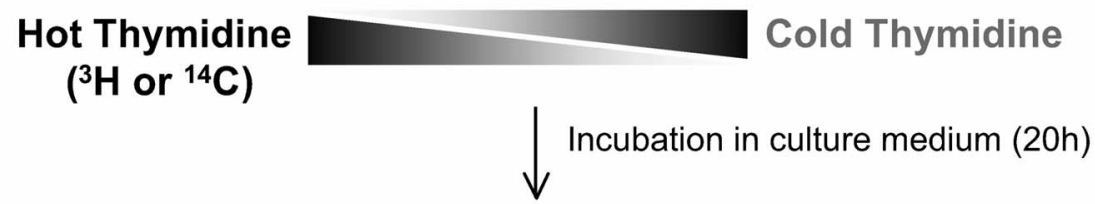

Cells harvested and counted

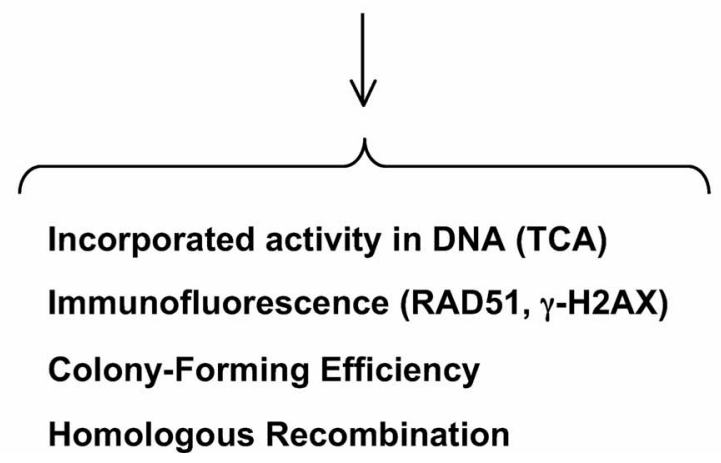

FIG. 1. Cell lines used. Panel A: Homologous recombination substrate. This substrate contains a direct repeat of two inactive neomycin-resistant (NEO) genes. The parental cells are sensitive to G418. Recombination restores a functional NEO gene. Recombinants are resistant to G418 (12). Panel B: Expression of the RAD51 dominant negative SMRAD51, measured by Western blot analysis (13). The two bands indicate SMRAD51 expression. Panel C: Names and characteristics of the different cell lines used here. Panel D: Experimental design. Cells were cultured in the presence of different specific activities of $\left[{ }^{3} \mathrm{H}\right]$ or $\left[{ }^{14} \mathrm{C}\right]$ thymidine. The final concentration of thymidine was kept constant using cold thymidine. After $20 \mathrm{~h}$ of incubation, when incorporation reached a plateau, over $95 \%$ of cells contained labeled nucleotides. Incorporated radioactivity was counted in the trichloroacetic acid (TCA) precipitate. Viability (colony-forming efficiency) and recombination frequency were measured. 

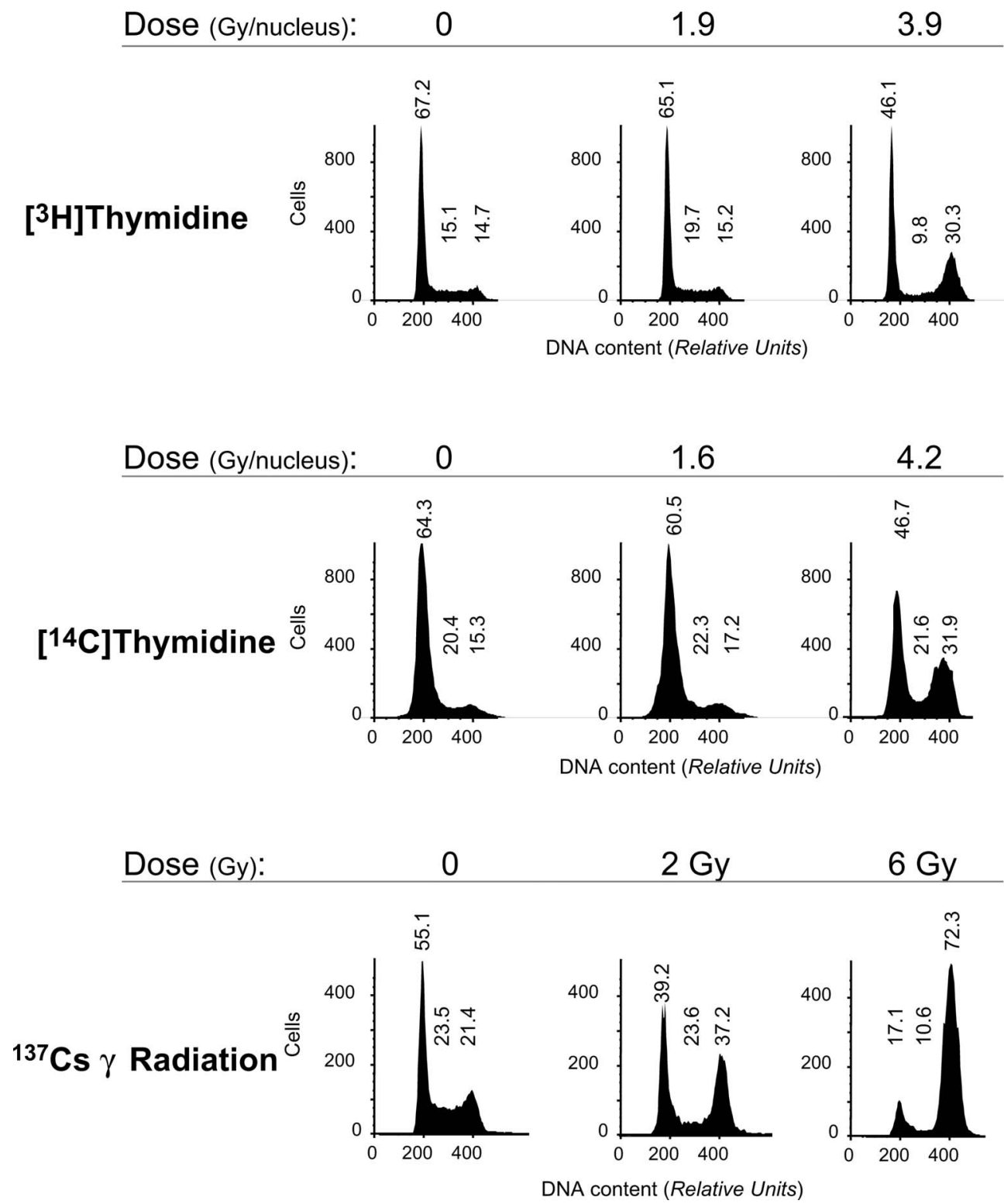

FIG. 2. Effect of incorporation of labeled thymidine $\left({ }^{3} \mathrm{H}\right.$ or $\left.{ }^{14} \mathrm{C}\right)$ on cell cycle progression. Cell cycle phases were determined by DNA content measured by flow cytometry for cells harvested immediately after incorporation of $\left[{ }^{3} \mathrm{H}\right]$ thymidine and $\left[{ }^{14} \mathrm{C}\right]$ thymidine. For external $\gamma$ radiation $\left({ }^{137} \mathrm{Cs}\right)$, cell cycle phases were determined in cells harvested $20 \mathrm{~h}$ after irradiation. Percentages of cell in $\mathrm{G}_{1}, \mathrm{~S}$ and $\mathrm{G}_{2} / \mathrm{M}$ are indicated on each profile. Cell cycle analyses were performed in three independent experiments.

sorter (FACS) to measure the impact of the radioactivity on cell cycle distributions. In wild-type CHO-DRA10 cells, no modifications in cell cycle distributions were recorded for incorporation of $\left[{ }^{3} \mathrm{H}\right]$ or $\left[{ }^{14} \mathrm{C}\right]$ thymidine up to 1.94 or 1.59 Gy/nucleus, respectively. In contrast, 2 Gy of $\gamma$ rays generated marked $\mathrm{G}_{2}$ arrest $20 \mathrm{~h}$ after irradiation (Fig. 2). However, increasing the incorporated doses of the $\beta$-particle emitters generated transient blocks in $\mathrm{G}_{2} / \mathrm{M}$. The $\mathrm{G}_{2}$ blocks were detectable for doses of 3.93 and 4.18 Gy/nucleus of $\left[{ }^{3} \mathrm{H}\right]$ and $\left[{ }^{14} \mathrm{C}\right]$ thymidine, respectively. Lower doses of labeled nucleotide incorporation were not sufficient to provoke a detectable cell cycle arrest.
Cell Viability after $\left[{ }^{14} \mathrm{C}\right]$ or $\left[{ }^{3} \mathrm{H}\right]$ Thymidine Incorporation: Impact of Low and Higher Incorporated Doses

$\left[{ }^{3} \mathrm{H}\right]$ Thymidine and $\left[{ }^{14} \mathrm{C}\right]$ thymidine exhibited comparable $\mathrm{LD}_{50} \mathrm{~s}$ of 3.24 and $2.98 \mathrm{~Gy} /$ nucleus, respectively (Fig. 3A and $\mathrm{B}$ ). However, the dose-response curve was biphasic for $\left[{ }^{3} \mathrm{H}\right]$ thymidine and linear for $\left[{ }^{14} \mathrm{C}\right]$ thymidine. At the lowest doses $(<1 \mathrm{~Gy} /$ nucleus $),\left[{ }^{3} \mathrm{H}\right]$ thymidine was significantly more toxic than $\left[{ }^{14} \mathrm{C}\right]$ thymidine $(P<0.0001$; compare Fig. $3 \mathrm{~A}$ and $\mathrm{B}$ ). At $0.50 \mathrm{~Gy} /$ nucleus, the mean viabilities were $69 \%$ for $\left[{ }^{3} \mathrm{H}\right]$ thymidine and $90 \%$ for $\left[{ }^{14} \mathrm{C}\right]$ thymidine, and the $\mathrm{LD}_{30} \mathrm{~s}$ were $0.47 \mathrm{~Gy} /$ nucleus and $1.53 \mathrm{~Gy} /$ nucleus for incorporated $\left[{ }^{3} \mathrm{H}\right]$ and $\left[{ }^{14} \mathrm{C}\right]$ thymidine, respectively. 
A

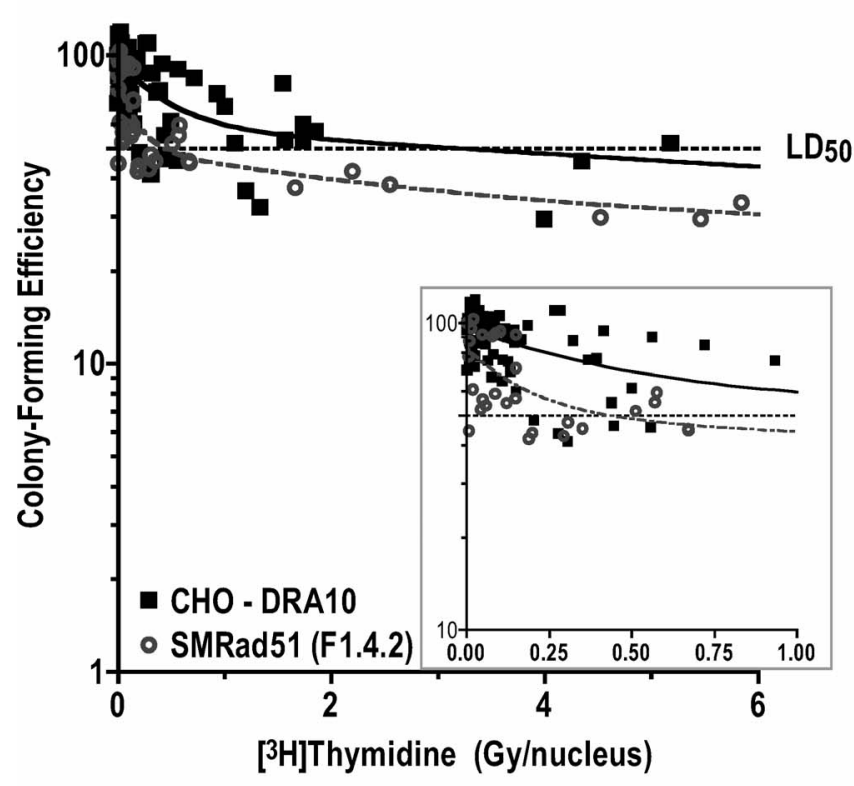

C

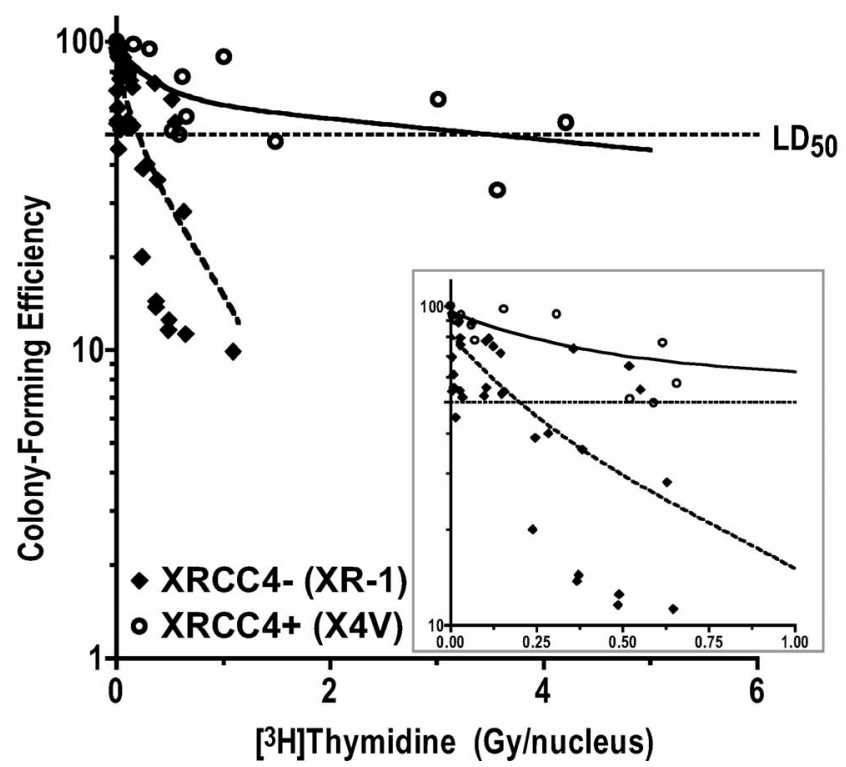

B
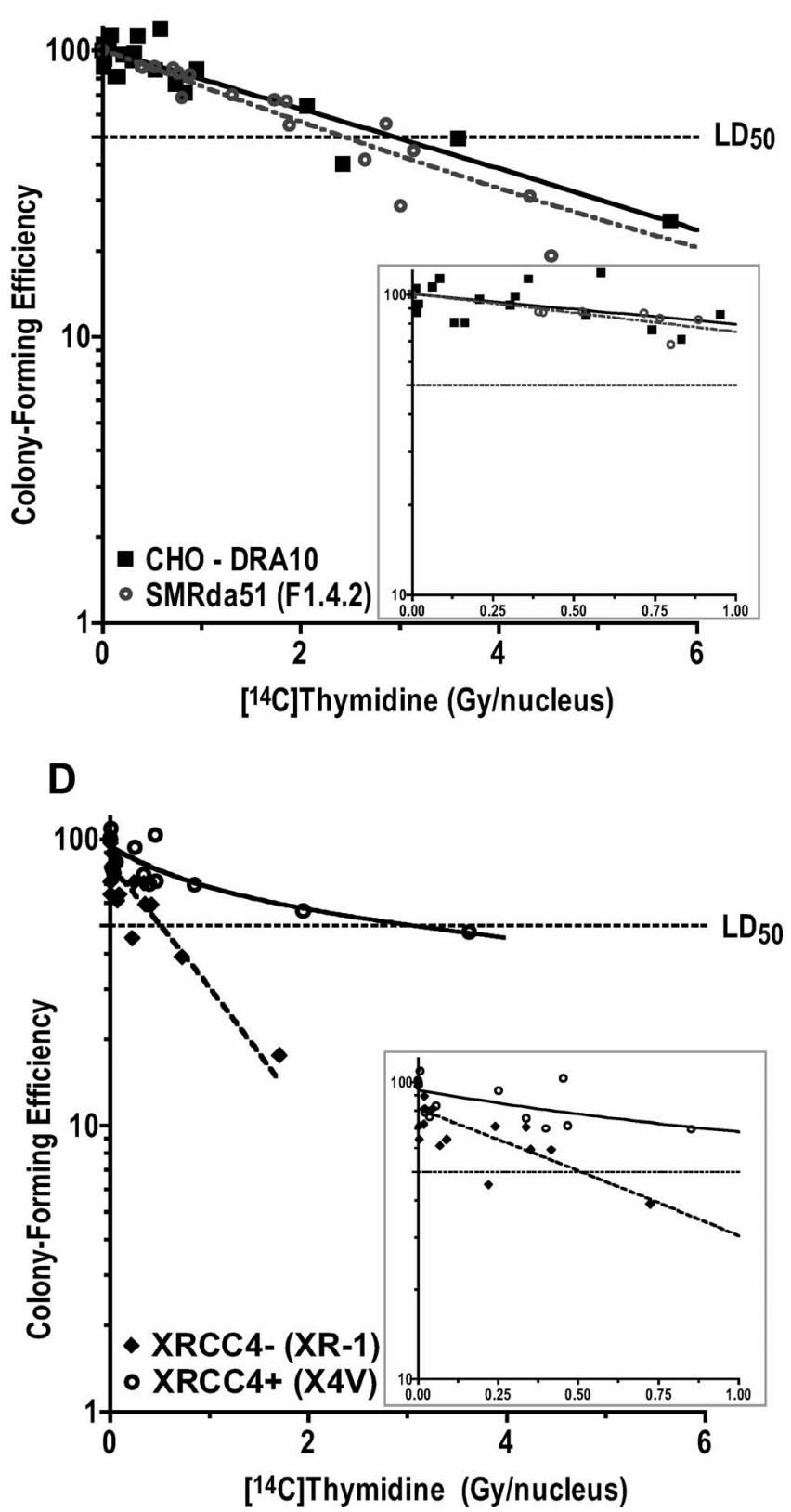

FIG. 3. Effect of incorporation of labeled thymidine $\left({ }^{3} \mathrm{H}\right.$ or $\left.{ }^{14} \mathrm{C}\right)$ on survival. Panel A: $\left[{ }^{3} \mathrm{H}\right]$ Thymidine incorporation in CHO-DRA10 and SMRAD51 cells. A decrease in colony-forming efficiency (CFE) is significantly linked to $\left.{ }^{3} \mathrm{H}\right]$ thymidine incorporation in both CHO-DRA10 and SMRAD51 cells $(P<0.0001)$. Panel B: $\left[{ }^{14} \mathrm{C}\right]$ Thymidine incorporation in CHO-DRA10 and SMRAD51 cells. A decrease in colony-forming efficiency is significantly linked to $\left[{ }^{14} \mathrm{C}\right]$ thymidine incorporation in both CHO-DRA10 and SMRAD51 cells $(P<0.0001)$. Panel C: $\left[{ }^{3} \mathrm{H}\right]$ Thymidine incorporation in $x r c c 4^{-}$ (NHEJ-deficient) and $\mathrm{xrct}^{+}$(control) cells. A decrease in colony-forming efficiency is significantly linked to [ $\left.{ }^{3} \mathrm{H}\right]$ thymidine incorporation in $\mathrm{XR}-1$ and X4V cells $(P<0.0001)$. Panel D: $\left[{ }^{14} \mathrm{C}\right]$ Thymidine incorporation in $x r c c 4^{-}$(NHEJ-deficient) and $x r c c 4^{+}$(control) cells. A decrease in colonyforming efficiency is significantly linked to $\left[{ }^{14} \mathrm{C}\right]$ thymidine incorporation in XR-1 and X4V cells $(P<0.0001)$. Toxicities at low doses are shown in the insets. Scatter plots are combined data from at least three independent experiments.

Impact of the HR and NHEJ Pathways on Cell Survival after Incorporation of Labeled Thymidine

RAD51 has been shown to control $\gamma$-ray-induced HR, and dominant negative SMRAD51 has been shown to inhibit HR induced by $\gamma$ rays without increasing sensitivity (13). At low doses ( $<1$ Gy/nucleus), the HR-defective cells (SMRAD51) showed a slight but significantly greater sen- sitivity to incorporation of $\left[{ }^{3} \mathrm{H}\right]$ thymidine than did the wildtype CHO-DRA10 cells $(P<0.0001 ;$ Fig. 3A). However, at higher doses (1 Gy/nucleus); i.e., in the second phase, the two curves evolved in parallel, indicating that the HRdefective cells were not more sensitive than wild-type cells to higher doses from incorporated $\left[{ }^{3} \mathrm{H}\right]$ thymidine (Fig. 3A). As a consequence, the calculated $\mathrm{LD}_{50}$ decreased from 3.24 
Gy/nucleus to $0.42 \mathrm{~Gy} /$ nucleus in the wild-type and HRdeficient cells, respectively. Thus HR-deficient cells appeared to be over sevenfold more sensitive to the incorporated of $\left[{ }^{3} \mathrm{H}\right]$ thymidine than were control cells. Importantly, sensitivity appeared to be due to low but not high doses from incorporation $\left[{ }^{3} \mathrm{H}\right]$ thymidine.

For $\left[{ }^{14} \mathrm{C}\right]$ thymidine, the $\mathrm{LD}_{50}$ values were similar in wildtype cells (mean $=2.98 \mathrm{~Gy} /$ nucleus) and in HR-deficient cells (mean $=2.46$ Gy/nucleus) (Fig. 3B). More specifically, the HR-defective cells (SMRAD51) were not more sensitive to lower doses of $\left[{ }^{14} \mathrm{C}\right]$ thymidine (Fig. 3B), which was consistent with $\left[{ }^{14} \mathrm{C}\right]$ thymidine failing to show increased toxicity at lower doses.

HR-defective mutants are only moderately sensitive to ionizing radiation. More specifically, SMRAD51-expressing cells are not sensitive to ionizing radiation, although gene conversion is strongly impaired $(13,18)$. In contrast, NHEJ-deficient mutants are highly sensitive to ionizing radiation. Thus we measured the impact of incorporation of labeled thymidine on the viability of the NHEJ-defective XR-1 cells, which are mutated in the XRCC4 gene (Fig. 3C and D).

While the wild-type CHO-DRA10 cells and the X4V cells, which correspond to the mutant XR-1 complemented with the XRCC4 cDNA, exhibited similar $\mathrm{LD}_{50}$ values (compare Fig. 3C and D to Fig. 3A and B), the $x_{r c c 4}{ }^{-}$ mutant cells showed a significantly greater sensitivity to incorporated $\left[{ }^{3} \mathrm{H}\right]$ thymidine at both low and high doses $(P$ $<0.0001$; Fig. 3C). At 0.97 Gy/nucleus, the viability of $x r c c 4^{-}$mutant cells was only $10 \%$, compared with $74 \%$ and $82 \%$ for $\mathrm{X} 4 \mathrm{~V}$ and $\mathrm{CHO}-\mathrm{DRA} 10$ cells, respectively. The $\mathrm{LD}_{50}$ decreased from a mean of $3.24 \mathrm{~Gy} /$ nucleus for $\mathrm{X} 4 \mathrm{~V}$ or CHO-DRA10 cells to $0.23 \mathrm{~Gy} /$ nucleus for the XR-1 mutant $\left(x r c c 4^{-}\right)$(Fig. 3A and C). Thus $x r c c 4^{-}$cells are 15fold more sensitive to incorporated $\left[{ }^{3} \mathrm{H}\right]$ thymidine than control cells. Interestingly, although the NHEJ mutant is more sensitive to ionizing radiation than HR-defective cells, their sensitivities were similar to low doses from incorporated $\left[{ }^{3} \mathrm{H}\right]$ thymidine $(P=0.12)$. In contrast, strong differences appeared at higher doses (compare Fig. 3A and B).

For $\left[{ }^{14} \mathrm{C}\right]$ thymidine, the mean $\mathrm{LD}_{50}$ was $2.67 \mathrm{~Gy} /$ nucleus for the complemented cells and only $0.51 \mathrm{~Gy} /$ nucleus for the $\mathrm{xrcc}^{-}$mutant cells (Fig. 3D). This indicates that $\mathrm{xrcc}^{-}$ cells are five times more sensitive to the incorporated $\left[{ }^{14} \mathrm{C}\right]$ thymidine than complemented cells $(P<0.0001)$. Interestingly, comparisons of the $\mathrm{LD}_{50} \mathrm{~s}$ revealed that $\left[{ }^{3} \mathrm{H}\right]$ thymidine was twofold more toxic than $\left[{ }^{14} \mathrm{C}\right]$ thymidine in XRCC4-defective cells $(P<0.0001$; compare Fig. 3C and $\mathrm{D})$.

\section{Incorporated $\left[{ }^{3} \mathrm{H}\right]$ or $\left[{ }^{14} \mathrm{C}\right]$ Thymidine Induces Formation} of $\gamma$-H2AX Foci

Since cells deficient in DSB repair are sensitive to $\left[{ }^{3} \mathrm{H}\right]$ or $\left[{ }^{14} \mathrm{C}\right]$ thymidine, it is conceivable that $\left[{ }^{3} \mathrm{H}\right]$ or $\left[{ }^{14} \mathrm{C}\right]$ thymidine can induce DSBs. We therefore analyzed the formation of $\gamma$-H2AX foci after incorporation of $\left[{ }^{3} \mathrm{H}\right]$ thymidine at non-lethal doses (Fig. 4A). After generation of DSBs, H2AX is phosphorylated $(\gamma-\mathrm{H} 2 \mathrm{AX})$ and is detectable as nuclear foci at the damaged sites $(19,20)$ in a linear relationship with the number of induced DSBs (21).

The percentages of cells with $\gamma-\mathrm{H} 2 \mathrm{AX}$ foci increased significantly as a function of incorporated $\left[{ }^{3} \mathrm{H}\right]$ or $\left[{ }^{14} \mathrm{C}\right]$ thymidine but required more than $0.16 \mathrm{~Gy} /$ nucleus and $0.11 \mathrm{~Gy} /$ nucleus, respectively, for detection above background levels (Fig. 4B to E). We then measured the mean number of $\gamma$-H2AX foci per cell after $\left[{ }^{3} \mathrm{H}\right]$ or $\left[{ }^{14} \mathrm{C}\right]$ thymidine incorporation. With $\gamma$ rays, there is a linear relationship between the number of $\gamma-\mathrm{H} 2 \mathrm{AX}$ foci and the estimated number of DSBs (21). This allows us to extrapolate an estimate for $\left[{ }^{3} \mathrm{H}\right]$ or $\left[{ }^{14} \mathrm{C}\right]$ thymidine-induced DSBs. Both the mean number of $\gamma$-H2AX foci/cells (Fig. 4B and D) and the frequency of cells with $\gamma-\mathrm{H} 2 \mathrm{AX}$ foci (Fig. 4C and $\mathrm{E}$ ) increased as a function of the incorporated dose. Interestingly, the mean number of $\gamma-\mathrm{H} 2 \mathrm{AX}$ foci was significantly higher in NHEJ-defective cells than in complemented cells $(P<0.0001$; Fig. 4D).

Foci form immediately after irradiation, after which they disappear in a few hours due to DSB repair. In the present work, $\gamma-\mathrm{H} 2 \mathrm{AX}$ foci were analyzed at the end of the incubation with labeled nucleotides (after $20 \mathrm{~h}$ incubation). The frequencies of foci resulted from the countervailing influences of DSB repair (focus extinction) and the generation of new DSBs (focus formation) at the time of monitoring (i.e., the latest incubation times). The increased accumulation of $\gamma$-H2AX foci in $x r c c 4$-defective cells is consistent with their DSB repair defect and accounts for their greater sensitivity (see Fig. 3C and 3D). Taken together, these data indicate that either $\left[{ }^{3} \mathrm{H}\right]$ thymidine or $\left[{ }^{14} \mathrm{C}\right]$ thymidine can induce DSBs, which are processed by the XRCC4 pathway. In contrast, SMRAD51 cells did not show significantly more $\gamma$-H2AX foci compared with wild-type cells (Fig. $4 \mathrm{~B}$ ), which is consistent with these cells being not sensitive to the high doses of labeled nucleotides required to induce $\gamma$-H2AX foci (see Fig. 3A and 3B).

\section{Incorporation of Non-lethal Levels of $\left[{ }^{3} \mathrm{H}\right]$ or $\left[{ }^{14} \mathrm{C}\right]$ Thymidine Strongly Stimulates the RAD51 Gene Conversion HR Pathway}

Ionizing radiation and DSBs stimulate $\mathrm{HR}$ in $\mathrm{p} 53^{-}$cells $(12,13,22,23)$. In the CHO-DRA10 cells used here, $\gamma$ rays stimulated HR (13) at highly toxic doses (compare Fig. $5 \mathrm{~A}$ and $\mathrm{B}$ ). Indeed, $\gamma$ rays significantly induced $\mathrm{HR}$, but only at doses resulting in $10 \%$ to $20 \%$ survival (Fig. 5B). In contrast, incorporation of $\left[{ }^{3} \mathrm{H}\right]$ thymidine and $\left[{ }^{14} \mathrm{C}\right]$ thymidine strongly stimulated $\mathrm{HR}$ at doses leading to survivals between $60 \%$ and $100 \%$ (compare Figs. 5C and $\mathrm{D}$ and $3 \mathrm{~A}$ and $\mathrm{B})$. Consistent with its higher toxicity at lower doses, $\left[{ }^{3} \mathrm{H}\right]$ thymidine stimulated $\mathrm{HR}$ at lower doses than ${ }^{14} \mathrm{C}(P<0.0001)$ and then reached a plateau that was at least twofold higher with $\left[{ }^{3} \mathrm{H}\right]$ thymidine than with 
A
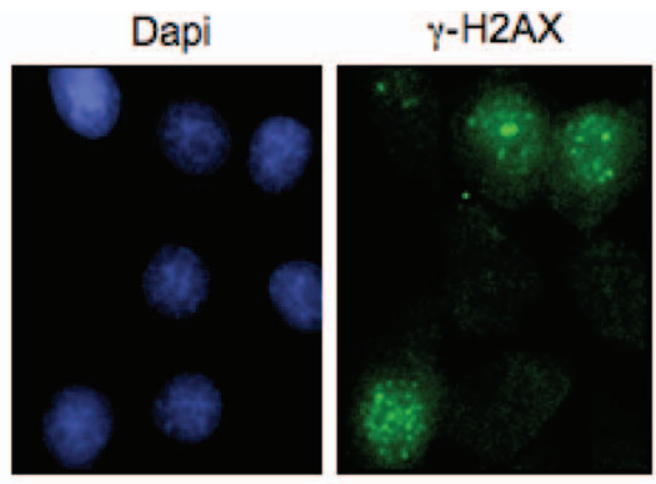

B

\section{$\left[{ }^{3} \mathrm{H}\right]$ Thymidine}

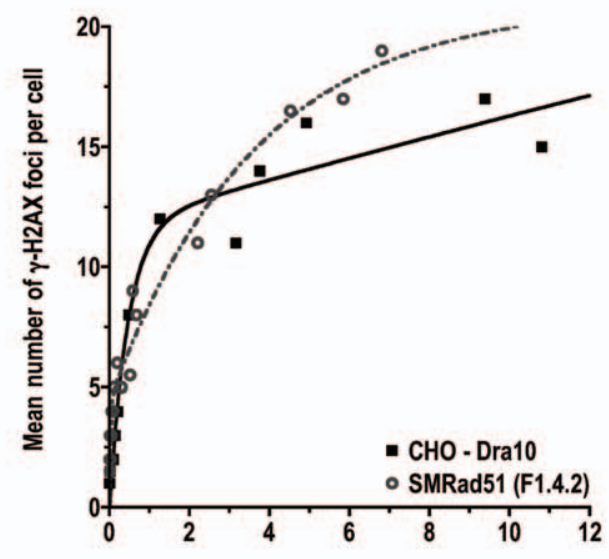

[3H]Thymidine incorporation (Gy/nucleus) $\left[{ }^{14} \mathrm{C}\right]$ Thymidine

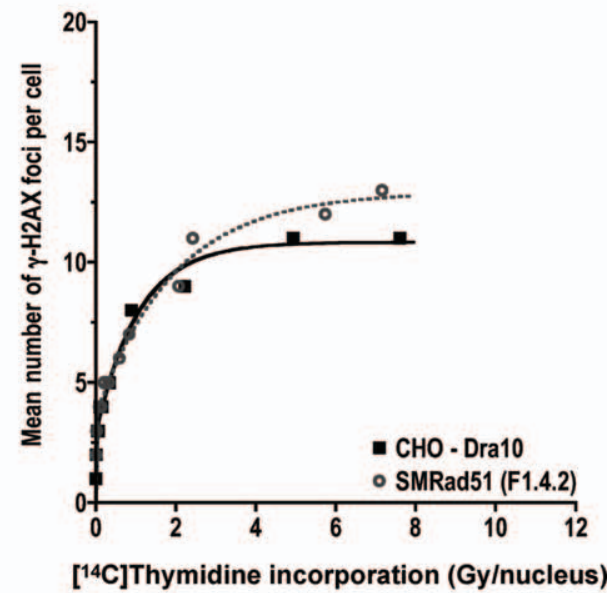

C
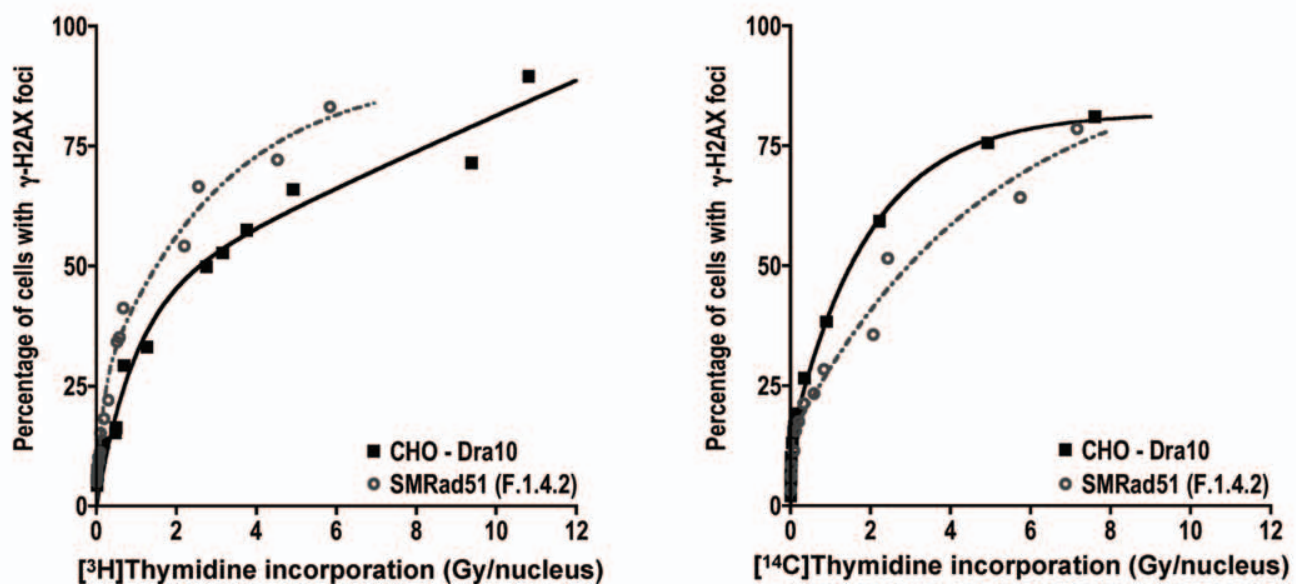

FIG. 4. $\gamma$-H2AX foci induced by $\left[{ }^{3} \mathrm{H}\right]$ or $\left[{ }^{14} \mathrm{C}\right]$ thymidine. Panel A: Example of $\gamma$-H2AX foci (contamination of CHO-DRA10 with $\left[{ }^{3} \mathrm{H}\right]$ thymidine at 1.29 Gy/nucleus). Panel B: Mean number of $\gamma$-H2AX foci per cell as a function of the incorporated dose in CHO-DRA10 and SMRAD51 cells. The mean number of $\gamma-\mathrm{H} 2 \mathrm{AX}$ foci per cell is significantly linked to $\left[{ }^{3} \mathrm{H}\right]$ thymidine incorporation (left frame; $P<0.0001$ ) and $\left[{ }^{14} \mathrm{C}\right]$ thymidine incorporation (right frame; $P<0.0001)$ in CHO-DRA10 and SMRAD51 cells. Panel C: Percentage of cells with $\gamma$-H2AX foci as a function of the incorporated dose in CHO-DRA10 and SMRAD51 cells. The percentage of $\gamma$-H2AX foci is significantly linked to both $\left[{ }^{3} \mathrm{H}\right]$ thymidine incorporation (left frame) and $\left[{ }^{14} \mathrm{C}\right]$ thymidine incorporation (right frame) in CHO-DRA10 and SMRAD51 cells $(P<0.0001)$. Panel D: Mean number of $\gamma$-H2AX foci per cell as a function of the incorporated dose in XR-1 and X4V cells. The mean number of $\gamma-\mathrm{H} 2 \mathrm{AX}$ foci per cell is significantly linked to 
$\left[{ }^{14} \mathrm{C}\right]$ thymidine (Fig. 5C). For doses resulting in comparable levels of viability (60 to $100 \%$ ), no $\gamma$-ray-induced HR was recorded. Moreover, the maximum HR stimulation produced by a $\gamma$-ray dose resulting in $10 \%$ survival (6 Gy) was very low compared with the HR stimulation induced by non-lethal doses.

SMRAD51 has been shown to efficiently inhibit the induction of HR by $\gamma$ rays (13). We also found that SMRAD51 completely abolished HR induced by incorporation of labeled thymidine (Fig. 5C and D).

After genotoxic stress, the pivotal HR protein RAD51 assembles into nuclear foci at DNA damage sites, which are thought to represent recombination/repair centers $(16,19,24$, 25 ). RAD51 focus assembly seems to be a prerequisite for HR, because no HR events had been recorded previously when RAD51 assembly was impaired. We found here that
[ $\left.{ }^{3} \mathrm{H}\right]$ thymidine incorporation leads to RAD51 focus assembly (Fig. 6A). RAD51 foci were detectable at a dose of $0.09 \mathrm{~Gy} /$ nucleus $\left(3 \times 10^{4} \mathrm{dpm} / 10^{6}\right.$ cells $)$ and reached a plateau, with $50 \%$ of cells containing RAD51 foci at 0.32 Gy/nucleus. The dose-response curves for RAD51 focus assembly were consistent with those for induction of HR (compare Fig. 6B and 5C). Taken together, these data suggest that low doses from incorporation $\left[{ }^{3} \mathrm{H}\right]$ thymidine stimulate the RAD51-dependent gene conversion pathway.

\section{DISCUSSION}

In this work, we analyzed the impact of incorporation of $\left[{ }^{3} \mathrm{H}\right]$ or $\left[{ }^{14} \mathrm{C}\right]$ thymidine at the molecular level when a precise subcellular compartment, the nucleus, was targeted. Importantly, the relative impact of $\left[{ }^{3} \mathrm{H}\right]$ thymidine compared with
D

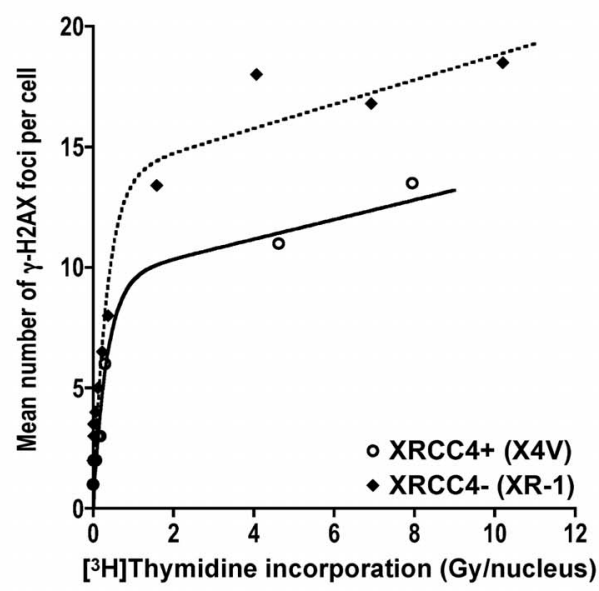

E

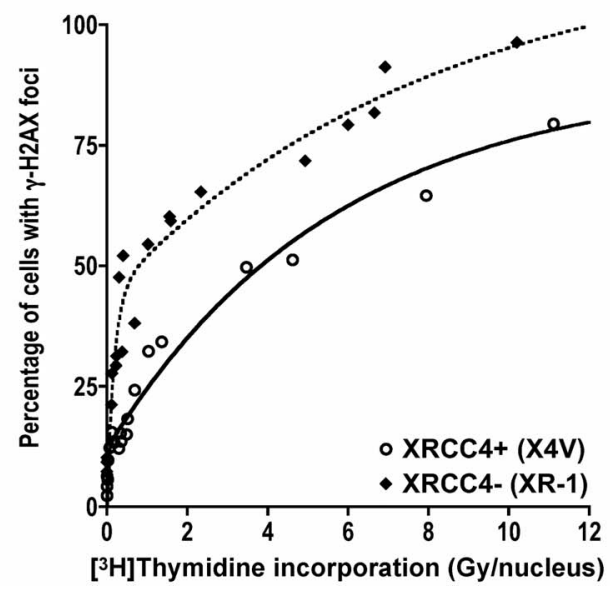

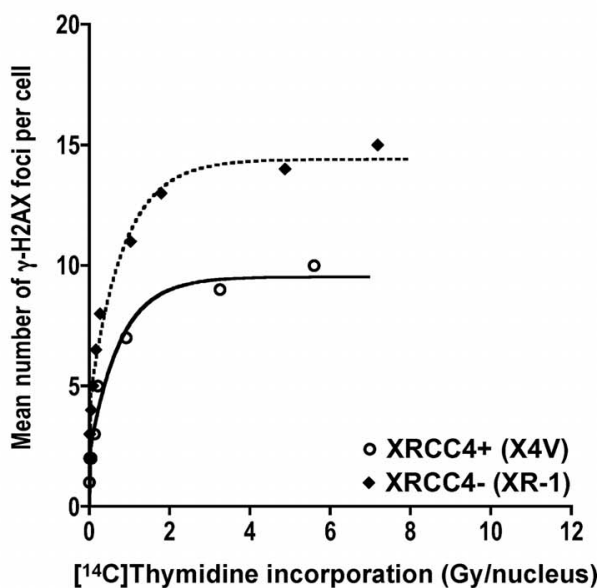

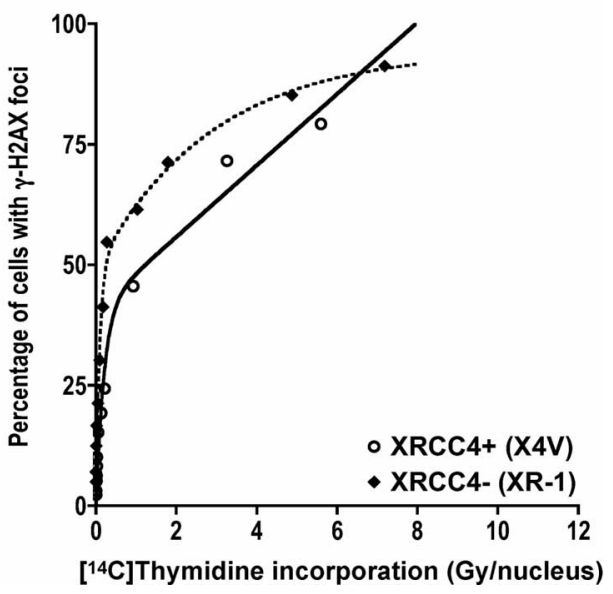

both $\left[{ }^{3} \mathrm{H}\right]$ thymidine incorporation (left frame) and $\left[{ }^{14} \mathrm{C}\right]$ thymidine incorporation (right frame) in XR-1 and X4V cells $(P<0.0001)$. Panel E: Percentage of cells with $\gamma-\mathrm{H} 2 \mathrm{AX}$ foci as a function of the incorporated dose in XR-1 and $\mathrm{X} 4 \mathrm{~V}$ cells. The percentage of $\gamma-\mathrm{H} 2 \mathrm{AX}$ foci is significantly linked to both $\left[{ }^{3} \mathrm{H}\right]$ thymidine incorporation (right frame) and $\left[{ }^{14} \mathrm{C}\right]$ thymidine incorporation (left frame ) in XR-1 and X4V cells $(P<0.0001)$. More than 100 nuclei were scored for each labeled thymidine incorporation. Scatter plots are combined data from at least three independent experiments. 
A

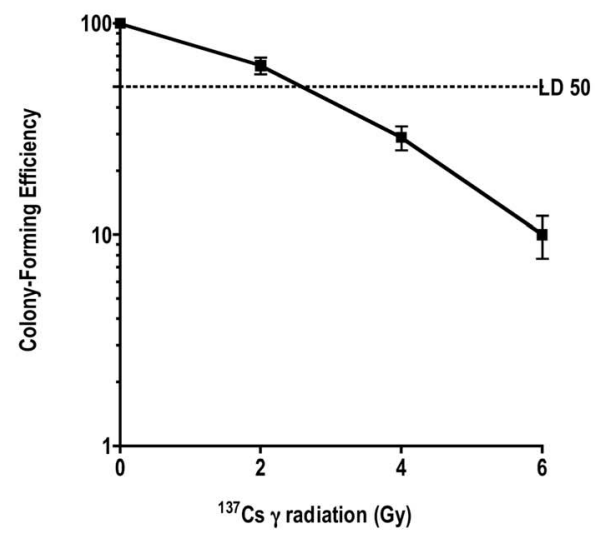

C

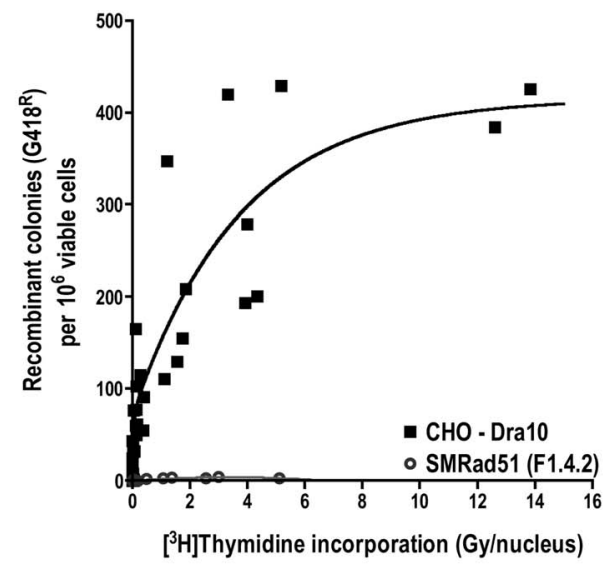

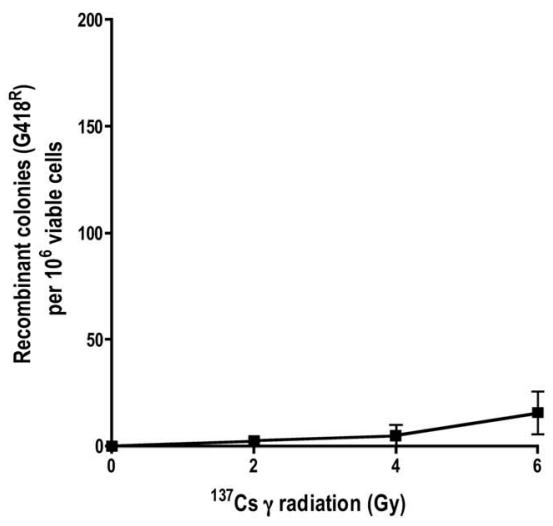

D

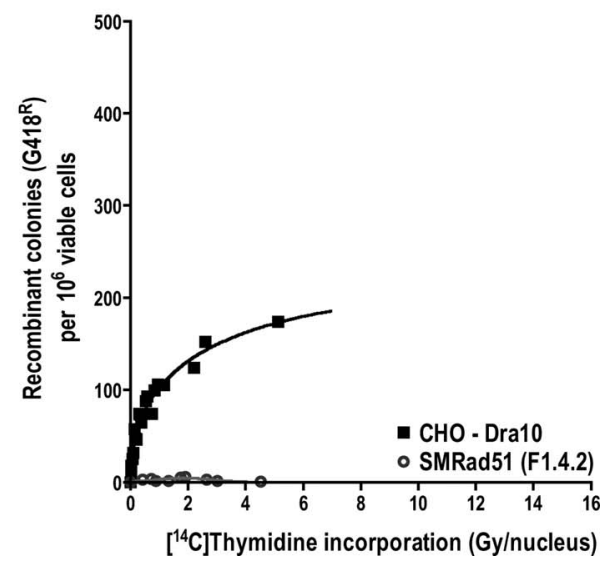

FIG. 5. Effects of $\gamma$ rays and $\left[{ }^{3} \mathrm{H}\right]$ or $\left[{ }^{14} \mathrm{C}\right]$ thymidine incorporation on homologous recombination. Panel A: Survival of CHO-DRA10 after $\gamma$ irradiation. Panel B: induction of HR by $\gamma$ rays. Panel C: HR induction as a function of $\left[{ }^{3} \mathrm{H}\right]$ thymidine incorporation. Impact of overexpression of the dominant negative form of RAD51, SMRAD51, on HR induced by incorporated $\left[{ }^{3} \mathrm{H}\right]$ thymidine. For CHO-DRA10 cells, the increase in HR is significantly linked to $\left[{ }^{3} \mathrm{H}\right]$ thymidine incorporation $(P<0.0001)$. Panel D: Induction of $\mathrm{HR}$ as a function of $\left[{ }^{14} \mathrm{C}\right]$ thymidine incorporation. Impact of overexpression of SMRAD51 on HR induced by incorporated $\left[{ }^{14} \mathrm{C}\right]$ thymidine. For CHODRA10 cells, increase in HR is significantly linked to $\left[{ }^{14} \mathrm{C}\right]$ thymidine incorporation $(P<0.0001)$. Scatter plots are combined data from at least three independent experiments.

$\left[{ }^{14} \mathrm{C}\right]$ thymidine incorporation depends on the dose and reveals a "low-dose" effect. Although the $\mathrm{LD}_{50} \mathrm{~s}$ were similar, $\left[{ }^{3} \mathrm{H}\right]$ thymidine was more toxic than $\left[{ }^{14} \mathrm{C}\right]$ thymidine at lower doses. In addition, we demonstrated that XRCC4- and RAD51-dependent pathways respond to incorporation of radioactivity by mammalian cells. Importantly, HR-defective cells showed increased sensitivity to lower doses from incorporated $\left[{ }^{3} \mathrm{H}\right]$ thymidine but not to either $\gamma$ rays or high doses from incorporated $\left[{ }^{3} \mathrm{H}\right]$ thymidine. In contrast, HR-defective cells do not appear to be hypersensitive to low doses of $\left[{ }^{14} \mathrm{C}\right]$ thymidine, consistent with the fact that this compound does not generate a "low-dose" effect. Importantly, the sensitivity to low doses of $\left[{ }^{3} \mathrm{H}\right]$ thymidine in HR-defective cells is similar to that of NHEJ-defective cells. The larger difference in viabilities between HR- and NHEJ-defective cells is revealed at high doses. Indeed, the sensitivity of HR-defective cells is restricted to low ${ }^{3} \mathrm{H}$ doses, while NHEJ-defective cells are sensitive to both low and high ${ }^{3} \mathrm{H}$ doses as well as to $\gamma$ rays. Thus the present work reveals a specific effect of low doses of low-energy incorporated isotopes on survival. The greater toxicity recorded in the HR mutant at low doses from incorporated $\left[{ }^{3} \mathrm{H}\right]$ thymidine demonstrate that the HR pathway plays a major role in repair of damages induced by tritium disintegration.

Finally, we show that incorporation of $\left[{ }^{3} \mathrm{H}\right]$ thymidine, and to a lesser extent $\left[{ }^{14} \mathrm{C}\right]$ thymidine, strongly stimulates 

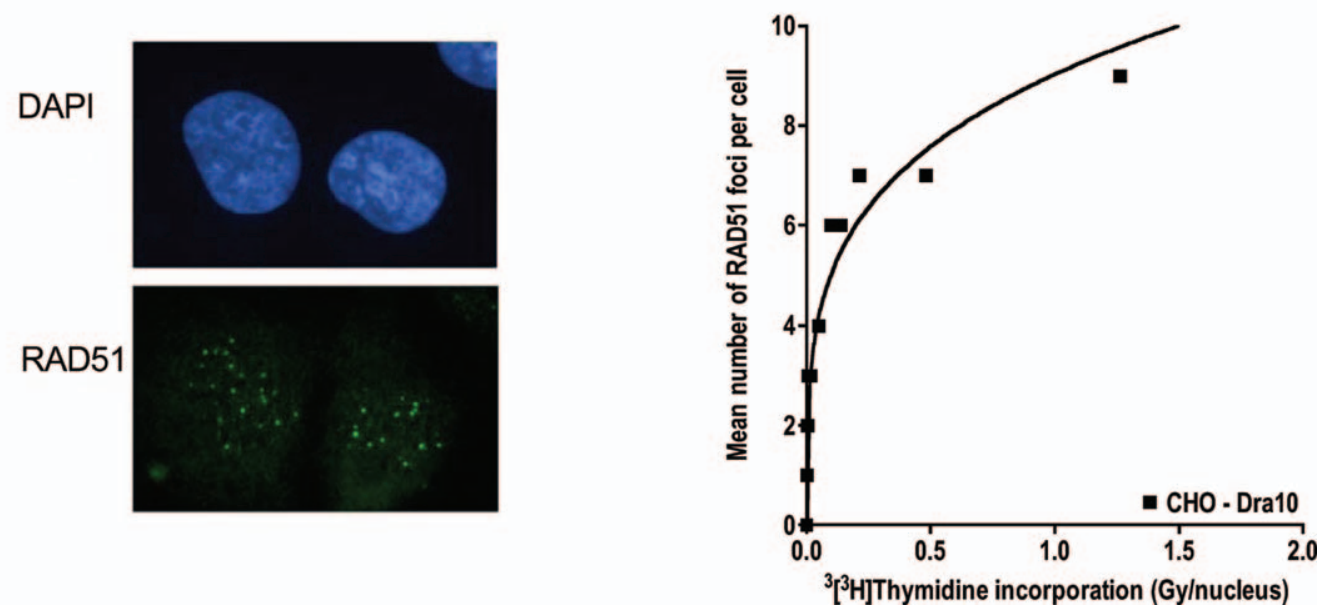

FIG. 6. $\left[{ }^{3} \mathrm{H}\right]$ Thymidine-induced RAD51 foci. Panel A: Example of RAD51 foci. Panel B: RAD51 focus formation as a function of the incorporated dose. The mean number of RAD51 foci per cell is significantly linked to $\left[{ }^{3} \mathrm{H}\right]$ thymidine incorporation $(P<0.0001)$. Data from at least three independent experiments.

HR, even without cell mortality. Such HR stimulation cannot be achieved with $\gamma$ rays, because they kill cells. HR induced by $\left[{ }^{3} \mathrm{H}\right]$ uracil occurs after relatively little tritium decay in Saccharomyces cerevisiae. However, in contrast to what was observed here in mammalian cells, $\left[{ }^{3} \mathrm{H}\right]$ uracil induces cell death and gene conversion at levels that are similar to those produced by an equivalent dose of $\gamma$ radiation in S. cerevisiae (10).

The risks for damage increase when the energy emitted by the radionuclide decreases. This can be explained by the fact that more total energy is deposited into the nucleus by a low-energy compound. Indeed, $\left[{ }^{3} \mathrm{H}\right]$ thymidine $(0.019$ $\mathrm{MeV}$ ), which deposits $68 \%$ of its energy in the nucleus, is more toxic and stimulates HR more efficiently than $\left[{ }^{14} \mathrm{C}\right]$ thymidine $(0.157 \mathrm{MeV})$, which deposits only $19 \%$ of its energy in the nucleus (1). This underscores the fact that the energy deposited into the nucleus is an essential parametric determinant of cell viability and genetic alteration after uptake of radioactive compounds and may be responsible for the toxicity and genetic effects at lower doses.

DSBs are highly toxic lesions that can be induced by ionizing radiations. Two mechanisms can repair DSBs: NHEJ and HR. NHEJ-defective cells are highly sensitive to ionizing radiation $(26,27)$. The fact that NHEJ mutant cells show increased sensitivity supports the model that incorporated $\left[{ }^{3} \mathrm{H}\right]$ or $\left[{ }^{14} \mathrm{C}\right]$ thymidine produces DSBs in the DNA. This conclusion is also supported by the formation of $\gamma$-H2AX foci upon incorporation of $\left[{ }^{3} \mathrm{H}\right]$ or $\left[{ }^{14} \mathrm{C}\right]$ thymidine. Alternatively, cells can take advantage of a homologous sequence to repair DSBs by HR processes. Ionizing radiations, and more specifically DSBs, stimulate HR in mammalian cells $(12,13,22,23)$ in a RAD51-dependent manner (13). Similarly, we showed here that labeled nucleotide incorporation stimulates HR and, among the different processes (28), gene conversion, which is a
RAD51-dependent pathway (13, 29-31). Taken together, these data are consistent with the idea that incorporated labeled nucleotides, even at non-lethal levels, cause genotoxic stress involving DSB production and gene conversion.

HR is essential to maintaining genome stability. However, HR should be precisely regulated, because an excess in HR can also result in chromosomal instability and disease (32-34). Indeed, recombination between repeated sequences dispersed throughout the genome can lead to deletions, amplifications, translocations or inversions (35). Overexpression of RAD51, which stimulates HR $(13,36-$ $38)$, has been reported in tumor cells $(39,40)$. Excess HR also has been reported in different precancerous situations, such as defects in p53 (35), ataxia telangiectasia (41) and expression of the oncogene kinase BCR-ABL (Philadelphia chromosome) involved in acute myeloid leukemia (42). In addition, accumulation of unprocessed HR intermediates leads to cytotoxicity and genomic instability $(43,44)$. These results emphasize the potential dangers of excess HR. On the basis of these considerations, the results presented here showing strong RAD51-HR stimulation in the absence of cell toxicity reveal a potential health risk from contamination, even at non-cytotoxic exposure levels.

Treatment with $\gamma$ rays produces DSBs and induces HR, but this induction is correlated with a marked decrease in cell viability. In asynchronous cells, $\gamma$-ray doses leading to $80 \%$ cell survival do not induce measurable HR. In contrast, low doses from incorporated $\left[{ }^{3} \mathrm{H}\right]$ or $\left[{ }^{14} \mathrm{C}\right]$ thymidine strongly induce HR. Incorporation of labeled nucleotide results in self-irradiation of DNA, with most of the energy deposited locally (i.e. in the DNA and in the nucleus). In contrast, $\gamma$-ray energy is deposited all along the paths and subcellular compartments that are crossed by the $\gamma$ rays (e.g. membranes and the cytoplasm). It is likely that irradiation of subcellular compartments increases toxicity. In 
addition, all the energy from $\gamma$ rays is deposited during a limited period ( $2 \mathrm{~Gy} / \mathrm{min})$, whereas the cells used here were exposed to labeled nucleotides for several hours. The difference in survival might reflect a dose-rate effect. Moreover, treatment with $\left[{ }^{3} \mathrm{H}\right]$ thymidine has been shown to protect against chromosomal instability induced by high doses of ionizing radiation, a process called the adaptive response (45). A microdosimetric model shows that the adaptive response works at very low doses. Indeed, in this model, the specific energy from single charged particles that hits the nucleus can activate the adaptive response (46). Since we have shown here that low doses of $\left[{ }^{3} \mathrm{H}\right]$ thymidine induce $\mathrm{HR}$, and since HR protects against genome instability, we speculate that HR may participate in the adaptive response.

In the present experiments, tritium was coupled to a nucleotide (thymidine), which is a DNA precursor. This situation is quite different from the intake of tritiated water, and the question arises as to the potential effect of low radiation doses from tritiated water. Cell lethality and chromosome aberrations have been recorded with tritiated water $(3,8,47,48)$. Moreover, sister chromatid exchanges were induced in bone marrow cells of mice treated with tritiated water (49), showing that DNA damage is induced by tritiated water. Finally, induction of HR by tritiated water has been described in $S$. cerevisiae (11).

In conclusion, incorporation of radioactive compounds into DNA leads efficiently to genomic rearrangements, with increased risks with lower-energy isotopes. The absence of cell toxicity represents an additional danger for multicellular organisms since the survival of cells carrying genomic rearrangements increases oncogenic risks. The ability of incorporated radioactivity to induce recombination without killing cells may have some bearing on the induction and transgenerational transmission of genetic alterations after contamination with radioisotopes.

\section{ACKNOWLEDGMENTS}

We thank Dr. P. Bertrand for stimulating discussions. This work was supported by Electricité de France (EDF), the "programme interorganisme ToxNuc-E", and by the European Communities under the contract of Association between EURATOM and CEA, carried out within the framework of the European Fusion Development Agreement. The views and opinions expressed herein do not necessarily reflect those of the European Commission.

Received: May 10, 2007; accepted: April 14, 2008

\section{REFERENCES}

1. NCRP, Tritium and Other Radionuclide Labeled Organic Compounds Incorporated in Genetic Material. Report No. 63, National Council on Radiation Protection and Measurements, Bethesda, MD, 1979.

2. M. I. Balonov, K. N. Muksinova and G. S. Mushkacheva, Tritium radiobiological effects in mammals: review of experiments of the last decade in Russia. Health Phys. 65, 713-726 (1993).

3. E. Bocian, B. Ziemb-Zak, O. Rosiek and J. Sablinski, Chromosome aberrations in human lymphocytes exposed to tritiated water in vitro. Curr. Top. Radiat. Res. Q. 12, 168-181 (1978).
4. J. Cleaver and $\mathrm{H}$. Burki, DNA damage and repair from ${ }^{3} \mathrm{H}$ and ${ }^{14} \mathrm{C}$ incorporated in macromolecules. Br. J. Radiol. 47, 739 (1974).

5. J. Cleaver, G. Thomas and H. Burki, Biological damage from intranuclear tritium: DNA strand breaks and their repair. Science 177, 996-998 (1972).

6. R. Painter and B. Young, Repair replication induced by ${ }^{3} \mathrm{H}$ incorporated into HeLa DNA. Mutat. Res. 22, 203-206 (1974).

7. A. M. Ueno, I. Furuno-Fukushi and H. Matsudaira, Induction of cell killing, micronuclei, and mutation to 6-thioguanine resistance after exposure to low-dose-rate gamma rays and tritiated water in cultured mammalian cells (L5178Y). Radiat. Res. 91, 447-456 (1982).

8. N. Vulpis, The induction of chromosome aberrations in human lymphocytes by in vitro irradiation with beta particles from tritiated water. Radiat. Res. 97, 511-518 (1984).

9. M. Yanokura, K. Takase, K. Yamamoto and H. Teraoka, Cell death and cell-cycle arrest induced by incorporation of $\left[{ }^{3} \mathrm{H}\right]$ thymidine into human haemopoietic cell lines. Int. J. Radiat. Biol. 76, 295-303 (2000).

10. H. Burki and E. Moustacchi, Tritium-induced lethal and genetic changes in Saccharomyces cerevisiae. Radiat. Res. 71, 635-640 (1977).

11. D. P. Morrison, R. V. Osborne and P. Unrau, Beta-ray-induced gene conversion in yeast. Radiat. Res. 87, 50-58 (1981)

12. F. Liang, M. Han, P. J. Romanienko and M. Jasin, Homology-directed repair is a major double-strand break repair pathway in mammalian cells. Proc. Natl. Acad. Sci. USA 95, 5172-5177 (1998).

13. S. Lambert and B. S. Lopez, Characterization of mammalian RAD51 double strand break repair using non lethal dominant negative forms. EMBO J. 19, 3090-3099 (2000).

14. M. Bryans, M. C. Valenzano and T. D. Stamato, Absence of DNA ligase IV protein in XR-1 cells: evidence for stabilization by XRCC4. Mutat. Res. 433, 53-58 (1999).

15. F. Delacote, M. Han, T. D. Stamato, M. Jasin and B. S. Lopez, An xrcc4 defect or Wortmannin stimulates homologous recombination specifically induced by double-strand breaks in mammalian cells. $\mathrm{Nu}$ cleic Acids Res. 30, 3454-3463 (2002).

16. T. Haaf, E. I. Golub, G. Reddy, C. M. Radding and D. C. Ward, Nuclear foci of mammalian Rad51 recombination protein in somatic cells after DNA damage and its localization in synaptonemal complexes. Proc. Natl. Acad. Sci. USA 92, 2298-2302 (1995).

17. E. P. Rogakou, C. Boon, C. Redon and W. M. Bonner, Megabase chromatin domains involved in DNA double-strand breaks in vivo. J. Cell. Biol. 146, 905-916 (1999).

18. F. Daboussi, J. Thacker and B. S. Lopez, Genetic interactions between RAD51 and its paralogues for centrosome fragmentation and ploidy control, independently of the sensitivity to genotoxic stresses. Oncogene 24, 3691-3696 (2005).

19. J. A. Aten, J. Stap, P. M. Krawczyk, C. H. Van Oven, R. A. Hoebe, J. Essers and R. Kanaar, Dynamics of DNA double-strand breaks revealed by clustering of damaged chromosome domains. Science 303, 92-95 (2004).

20. C. Redon, D. Pilch, E. Rogakou, O. Sedelnikova, K. Newrock and W. Bonner, Histone H2A variants H2AX and H2AZ. Curr. Opin. Genet. Dev. 12, 162-169 (2002).

21. K. Rothkamm and M. Lobrich, Evidence for a lack of DNA doublestrand break repair in human cells exposed to very low x-ray doses. Proc. Natl. Acad. Sci. USA 100, 5057-5762 (2003).

22. Y. Saintigny, D. Rouillard, B. Chaput, T. Soussi and B. S. Lopez, Mutant p53 proteins stimulate spontaneous and radiation-induced intrachromosomal homologous recombination independently of the alteration of the transactivation activity and of the G1 checkpoint. Oncogene 18, 3553-3563 (1999).

23. Y. Y. Wang, V. M. Maher, R. M. Liskay and J. J. McCormick, Carcinogens can induce homologous recombination between duplicated chromosomal sequences in mouse L cells. Mol. Cell. Biol. 8, 196202 (1988).

24. E. Raderschall, E. I. Golub and T. Haaf, Nuclear foci of mammalian recombination proteins are located at single-stranded DNA regions 
formed after DNA damage. Proc. Natl. Acad. Sci. USA 96, 19211926 (1999).

25. S. Tashiro, J. Walter, A. Shinohara, N. Kamada and T. Cremer, Rad51 accumulation at sites of DNA damage and in postreplicative chromatin. J. Cell. Biol. 150, 283-291 (2000).

26. P. A. Jeggo, Identification of genes involved in repair of DNA double-strand breaks in mammalian cells. Radiat. Res. 150 (Suppl.), S80-S91 (1998).

27. G. C. Smith and S. P. Jackson, The DNA-dependent protein kinase. Genes Dev. 13, 916-934 (1999).

28. F. Paques and J. E. Haber, Multiple pathways of recombination induced by double-strand breaks in Saccharomyces cerevisiae. Microbiol. Mol. Biol. Rev. 63, 349-404 (1999).

29. E. L. Ivanov, N. Sugawara, J. Fishman-Lobell and J. E. Haber, Genetic requirements for the single-strand annealing pathway of doublestrand break repair in Saccharomyces cerevisiae. Genetics 142, 693 704 (1996).

30. A. Malkova, E. L. Ivanov and J. E. Haber, Double-strand break repair in the absence of RAD51 in yeast: a possible role for break-induced DNA replication. Proc. Natl. Acad. Sci. USA 93, 7131-7136 (1996).

31. A. Malkova, M. L. Naylor, M. Yamaguchi, G. Ira and J. E. Haber, RAD51-dependent break-induced replication differs in kinetics and checkpoint responses from RAD51-mediated gene conversion. Mol. Cell. Biol. 25, 933-944 (2005).

32. M. Amor, K. L. Parker, H. Globerman, M. I. New and P. C. White, Mutation in the CYP21B gene (Ile-172-Asn) causes steroid 21-hydroxylase deficiency. Proc. Natl. Acad. Sci. USA 85, 1600-1604 (1988).

33. W. K. Cavenee, T. P. Dryja, R. A. Phillips, W. F. Benedict, R. Godbout, B. L. Gallie, A. L. Murphree, L. C. Strong and R. L. White, Expression of recessive alleles by chromosomal mechanisms in retinoblastoma. Nature 305, 779-784 (1983).

34. S. M. Purandare and P. I. Patel, Recombination hot spots and human disease. Genome Res. 7, 773-786 (1997).

35. P. Bertrand, Y. Saintigny and B. S. Lopez, p53's double life: transactivation-independent repression of homologous recombination. Trends Genet. 20, 235-243 (2004).

36. C. Arnaudeau, T. Helleday and D. Jenssen, The RAD51 protein supports homologous recombination by an exchange mechanism in mammalian cells. J. Mol. Biol. 289, 1231-1238 (1999).

37. Y. Huang, S. Nakada, T. Ishiko, T. Utsugisawa, R. Datta, S. Kharbanda, K. Yoshida, R. V. Talanian, R. Weichselbaum and Z. M. Yuan,
Role for caspase-mediated cleavage of Rad51 in induction of apoptosis by DNA damage. Mol. Cell. Biol. 19, 2986-2997 (1999).

38. S. Vispé, C. Cazaux, C. Lesca and M. Defais, Overexpression of Rad51 protein stimulates homologous recombination and increases resistance of mammalian cells to ionizing radiation. Nucleic Acids Res. 26, 2859-2864 (1998).

39. H. Maacke, K. Jost, S. Opitz, S. Miska, Y. Yuan, L. Hasselbach, J. Luttges, H. Kalthoff and H. W. Sturzbecher, DNA repair and recombination factor Rad51 is over-expressed in human pancreatic adenocarcinoma. Oncogene 19, 2791-2795 (2000).

40. E. Raderschall, A. Bazarov, J. Cao, R. Lurz, A. Smith, W. Mann, H. H. Ropers, J. M. Sedivy, E. I. Golub and T. Haaf, Formation of higherorder nuclear Rad51 structures is functionally linked to p21 expression and protection from DNA damage-induced apoptosis. J. Cell. Sci. 115, 153-164 (2002).

41. M. S. Meyn, High spontaneous intrachromosomal recombination rates in ataxia-telangiectasia. Science 260, 1327-1330 (1993).

42. A. Slupianek, C. Schmutte, G. Tombline, M. Nieborowska-Skorska, G. Hoser, M. O. Nowicki, A. J. Pierce, R. Fishel and T. Skorski, $\mathrm{BCR} / \mathrm{ABL}$ regulates mammalian RecA homologs, resulting in drug resistance. Mol. Cell 8, 795-806 (2001).

43. S. Gangloff, C. Soustelle and F. Fabre, Homologous recombination is responsible for cell death in the absence of the Sgs1 and Srs2 helicases. Nat. Genet. 25, 192-194 (2000).

44. Y. Saintigny, K. Makienko, C. Swanson, M. J. Emond and R. J. Monnat, Jr., Homologous recombination resolution defect in Werner syndrome. Mol. Cell. Biol. 22, 6971-6978 (2002).

45. G. Olivieri, J. Bodycote and S. Wolff, Adaptive response of human lymphocytes to low concentrations of radioactive thymidine. Science 223, 594-597 (1984).

46. B. Leonard, Adaptive response by single cell radiation hits-implications for nuclear workers. Radiat. Prot. Dosimetry 116, 387-391 (2005).

47. K. Tanaka, S. Sawada and N. Kamada, Relative biological effectiveness and dose rate effect of tritiated water on chromosomes in human lymphocytes and bone marrow cells. Mutat. Res. 323, 53-61 (1994).

48. W. Deng, D. P. Morrison, K. L. Gale and J. N. Lucas, Biological dosimetry of beta-ray exposure from tritium using chromosome translocations in human lymphocytes analyzed by fluorescence in situ hybridization. Radiat. Res. 150, 400-405 (1998).

49. T. Ikushima, R. Benz and A. Carsten, Sister chromatid exchanges in bone marrow cells of mice maintained on tritiated water. Int. J. Radiat. Biol. Relat. Stud. Phys. Chem. Med. 45, 251-256 (1984). 